\title{
Protective role of chlorogenic acid on DNA damage caused by ochratoxin A exposure
}

Campra, Noelia Anahí; Cariddi, Laura Noelia; Escobar, Franco Matías; Sabini, María Carola; Freire-de-Lim, Celio Geraldo; Decote-Ricardo, Debora; Roma, Dardo; Mañas, Fernando; Dalcero, Ana María Protective role of chlorogenic acid on DNA damage caused by ochratoxin A exposure ANALECTA VETERINARIA, vol. 40, no. 2, 2020

Universidad Nacional de La Plata, Argentina

https://doi.org/10.24215/15142590e049

Atribución no comercial sin derivar (CC BY-NC-ND) 4.0 


\title{
Protective role of chlorogenic acid on DNA damage caused by ochratoxin A exposure
}

\author{
Rol protector del ácido clorogénico sobre el daño del ADN causado por la exposición a ocratoxina A
}

Campra, Noelia Anahí \#

Instituto de Biotecnología Ambiental y Salud (INBIAS) CONICETUniversidad Nacional de Río Cuarto, Argentina

Cariddi, Laura Noelia *

lcariddi@exa.unrc.edu.ar Instituto de Biotecnología Ambiental y Salud (INBIAS) CONICET-

Universidad Nacional de Río Cuarto

Escobar, Franco Matías CONICET-Universidad Nacional de Río Cuarto, Argentina

ANALECTA VETERINARIA, vol. 40, no. 2,2020

Universidad Nacional de La Plata, Argentina

Received: 08 June 2020

Revised: 06 August 2020

Accepted: 21 August 2020

DOI: $10.24215 / 15142590 \mathrm{e} 049$

CC BY-NC-ND

\begin{abstract}
Sabini, María Carola
Instituto de Biotecnología Ambiental y Salud (INBIAS) CONICET-

Universidad Nacional de Río Cuarto, Argentina

Freire-de-Lima, Celio Geraldo

Instituto de Biofísica Carlos Chagas Filho, Universidade Federal do Rio de Janeiro, Brasil

Decote-Ricardo, Debora

Instituto de Veterinária, Universidade Federal Rural do Rio de Janeiro, Brasil
\end{abstract}

Roma, Dardo

Cátedra de Farmacología, Universidad Nacional de Río Cuarto, Argentina

Mañas, Fernando

Cátedra de Farmacología, Universidad Nacional de Río Cuarto, Argentina

Ana María Dalcero

Departamento de Microbiología e Inmunología, Universidad Nacional de Río Cuarto, Argentina

\# equal contribution

\begin{abstract}
Chlorogenic acid (ChlA) has shown short-term protective effects against the cytogenotoxic effects of ochratoxin A (OTA). The present study evaluated the effect of oral administration of ChlA in male Wistar rats exposed to OTA. OTA $(0.4 \mathrm{mg} / \mathrm{kg} \mathrm{bw} /$ day), ChlA ( $5 \mathrm{mg} / \mathrm{kg}$ bw/day), or the combination of both, were administered orally to animals during 28 days. No deaths, decrease in feed consumption or change in the body weight of animals were observed in any group. In the OTA-treated group a decrease in locomotion as well as increased DNA damage in blood, kidney and bone marrow cells were observed. ChlA alone was not genotoxic for animals. The combination of OTA +ChlA decreased the DNA damage by $37 \%$ in blood cells, by $55 \%$ in kidney cells and by $80 \%$ in bone marrow cells compared to OTA-treated group. In conclusion, oral treatment with ChlA showed a good protective effect on genotoxicity produced by OTA in rats during 28 days exposure.
\end{abstract}

Keywords: ochratoxin A, genotoxicity, chlorogenic acid. 


\begin{abstract}
Resumen
El ácido clorogé nico (ChlA) mostró efectos protectores a corto plazo contra los efectos citogenotóxicos de ocratoxina A (OTA). En el presente estudio se evaluó si este polifenol mantiene su efecto protector mediante la administración oral en ratas Wistar machos expuestas a OTA. OTA $(0,4 \mathrm{mg} / \mathrm{kg} /$ día $)$, ChlA $(5 \mathrm{mg} / \mathrm{kg} /$ día $)$, o la combinación de ambos, fueron administrados a los animales por vía oral durante 28 días. No se observaron muertes, ni disminución en el consumo de alimento, ni cambios en el peso corporal en ningún grupo de animales. En el grupo tratado con OTA se observó disminución en la locomoción, así como daño en el ADN en las células de sangre, riñón y médula ósea. En los animales que solo recibieron ChlA no se observaron efectos genotóxicos. La combinación de OTA + ChlA disminuyó el daño del $\mathrm{ADN}$ en un $37 \%$ en las células sanguíneas, en un $55 \%$ en las células renales y en un $80 \%$ en las células de la médula ósea con respecto al grupo tratado con OTA. En conclusión, el tratamiento oral con ChlA mostró buen efecto protector sobre la genotoxicidad producida por OTA en ratas durante 28 días de exposición.
\end{abstract}

Palabras clave: ocratoxina A, genotoxicidad, á cido clorogé nico.

\title{
Introduction
}

Ochratoxin A (OTA) is a toxic secondary metabolite produced by species of filamentous fungi of the genera Penicillium and Aspergillus, which grow on a wide range of organic substrates. This mycotoxin is present mainly in cereals for human consumption and animal feed as well as in alcoholic beverages, coffee and cocoa (Ravelo Abreu et al., 2011). Generally, monogastric and younger animals are more sensitive to mycotoxins than ruminant or older animals. The high ingestion of mycotoxins can cause deterioration of animal health as well as decreased production. Mycotoxicosis occurs with decrease in feed consumption and increase in morbidity and mortality rates (Muzaffer \& Pérez, 2006). The nephrotoxic, hepatotoxic, embryotoxic, teratogenic, neurotoxic, immunotoxic, genotoxic, and carcinogenic effects of OTA have already been demonstrated (Wang et al., 2020).

Polyphenols constitute one of the largest groups of non-energetic substances present in plants and foods of plant origin, with antioxidant properties that account for many of their beneficial effects (Quiñones et al., 2012). Different studies report that the toxic effects of mycotoxins could be reduced by polyphenols (Mazur-Kuśnirek et al., 2019). Chlorogenic acid (ChlA) is an important antioxidant polyphenol which is found in certain plants and is the main phenolic compound in coffee (Tajik et al., 2017). The protective effect of ChlA on cyto-genotoxicity induced by different toxic substances has been reported (CarranzaTorres et al., 2019). A previous study reported the short-term protective effects of ChlA on DNA damage induced by OTA in Balb/c mice after 24 hours of intraperitoneal treatment (Cariddi et al., 2015). The present study aimed to determine the possible protective effect of orally administered ChlA on DNA damage in rats exposed to OTA for 28 days by means of micronucleus assays in bone marrow cells and comet assays in blood and kidney cells. 


\section{Materials and methods}

\section{Reagents}

Ochratoxin A was purchased from BioPure Technology (UK); dimethylsulfoxide (DMSO) was obtained from Merck (Germany) and chlorogenic acid ( $\geq 95 \%$ ) was purchased from Sigma St. Louis, (USA). The doses of OTA $(0.4 \mathrm{mg} / \mathrm{kg}$ bw/day $)$ and ChlA $(5 \mathrm{mg} / \mathrm{kg}$ bw/day $)$ used, were based on a previous study (Cariddi et al., 2016). OTA and ChlA were dissolved in DMSO Merck (Germany)/phosphate buffered solution (PBS) (solvent concentration not exceeding $0.03 \%$ ).

\section{Experimental animals and treatments}

All experimental procedures were conducted in accordance with recent legislation. This study was approved by the Comité de Ética de la Investigación Cientifica (COEDI), Universidad Nacional de Río Cuarto (File No. 73/12) Male Wistar rats were used. The trials were performed with male rats because of their high susceptibility to OTA renal damage (Vettorazzi et al., 2014). Ten to twelve week old male Wistar rats (weighing 150-200 g), supplied from Bioterio of the Universidad Nacional de Rio Cuarto, were maintained in a temperature and humidity controlled room, with 12 hours light-dark cycles and food and water ad libitum. Briefly, animals were randomly divided into four groups (four animals per group; $\mathrm{n}=4)$ and treated individually by daily intragastric gavage during 28 days as follows: group 1: $0.2 \mathrm{ml} /$ day DMSO/PBS (Vehicle Control Group), group 2: OTA ( $0.4 \mathrm{mg} / \mathrm{kg}$ bw/day; OTA), group 3: ChlA (5 $\mathrm{mg} / \mathrm{kg}$ bw/day; ChlA), and group 4: a combination of OTA $(0.4 \mathrm{mg} /$ $\mathrm{kg}$ bw/day) and ChlA (5 mg/kg bw/day; OTA+ChlA). On day 29, animals were euthanized and blood samples were collected immediately with heparin for comet assay. The kidneys were dissected and stored at $-20{ }^{\circ} \mathrm{C}$ until further analysis by comet assay and the femurs were excised for micronucleus assay.

\section{Toxicity parameters}

The animals were examined once daily in order to observe toxicity reactions (hunched posture, waggling gait, decreased locomotion, aggressive behavior) and feed consumption. Body weight was recorded once a week.

\section{Comet assay for blood samples}

The heparinized blood samples were kept in the dark at $4{ }^{\circ} \mathrm{C}$ and processed within 6 hours. The comet assay was performed as described by Cariddi et al. (2015). 


\section{Comet assay for kidney samples}

Frozen kidney tissues were thawed at room temperature during preparation, and placed in cylindrical sieves which were filled with 1.5 $\mathrm{ml}$ ice-cold Merchant's medium $\left(0.14 \mathrm{M} \mathrm{NaCl}, 1.47 \mathrm{mM} \mathrm{KH}_{2} \mathrm{PO}_{4}, 2.7\right.$ $\mathrm{mM} \mathrm{KCl}, 8.1 \mathrm{mM} \mathrm{Na}_{2} \mathrm{HPO}_{4}, 10 \mathrm{mM} \mathrm{Na} 2$ EDTA, pH 7.4) The comet assay was performed according to the protocol proposed by Jackson $e t$ al. (2013). Tissues were homogenized by pressing through sieves as the plunger was moved up and down several times to obtain a cell suspension. The cells were trypsinized and suspended in PBS at a density of approximately $1 \times 10^{5}$ cells $/ \mathrm{ml}$. A $50 \mu \mathrm{l}$ aliquot of each cell suspension was added to $100 \mu \mathrm{l}$ of $0.75 \%$ low melting point agarose at $37^{\circ} \mathrm{C}$. The mixtures were layered onto slides pre-coated with $0.75 \%$ normal melting point agarose and covered with a coverslip. From this point forward, the protocol was identical to that used for the comet assay on blood samples.

\section{Micronucleus assay}

The assay was performed in bone marrow cells following standard protocols described by Cariddi et al. (2015).

\section{Statistical analysis}

Results were evaluated using GraphPad Prism version 5.00.288 (San Diego, USA, 2007) and compared with one-way analysis of variance (ANOVA) and the Tukey multiple comparison test or Kruskal Wallis test and Dunns multiple comparisons. The differences were considered to be statistically significant at $\mathrm{p}<0.05$.

\section{Results}

No deaths were recorded in any experimental group during the 28 days of the in vivo assay. However, the OTA-treated group showed decreased locomotion and overall less movement than other treatment groups. Rats treated with ChlA, OTA+ChlA and DMSO/PBS did not show reactions of toxicity. Neither decrease in feed consumption nor changes in body weight gain of animals were observed in any group (Figures $1 \mathrm{~A}$ and B). 
(A)

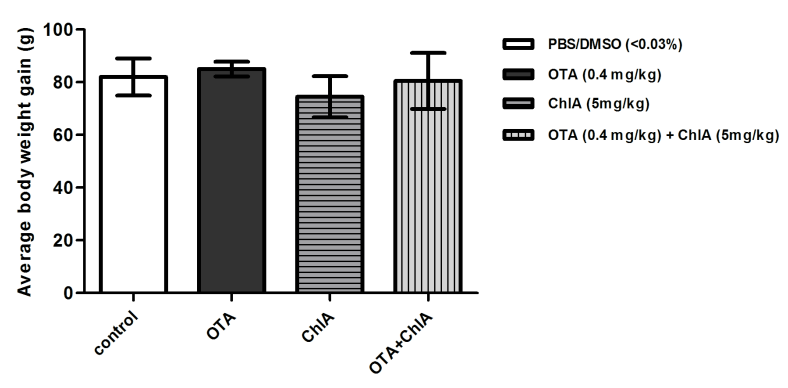

(B)

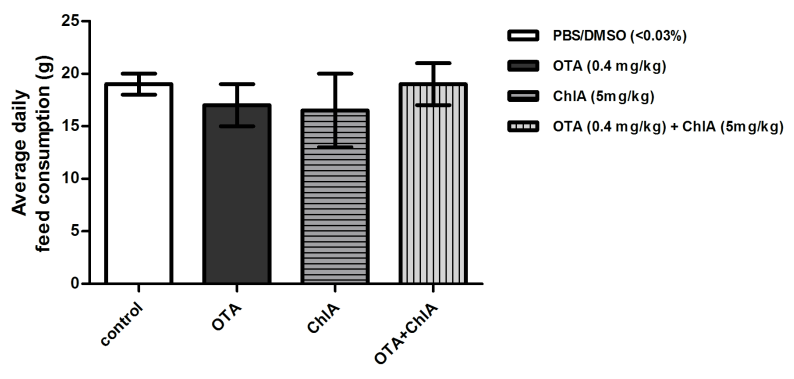

Figure 1. A) Average daily body weight gain and B) Average daily feed consumption of Wistar rats in the 28 days of treatment with ochratoxin A (OTA), chlorogenic acid (ChlA) or combination of OTA+ ChlA. Four rats were used per experimental group. Each value represents means Â SD. DMSO: dimethylsulfoxide. Statistical test: ANOVA and Tukey`s Test.

(A)

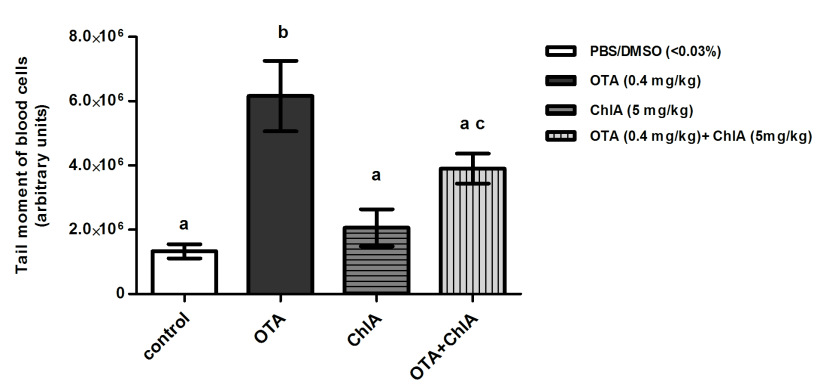

(B)

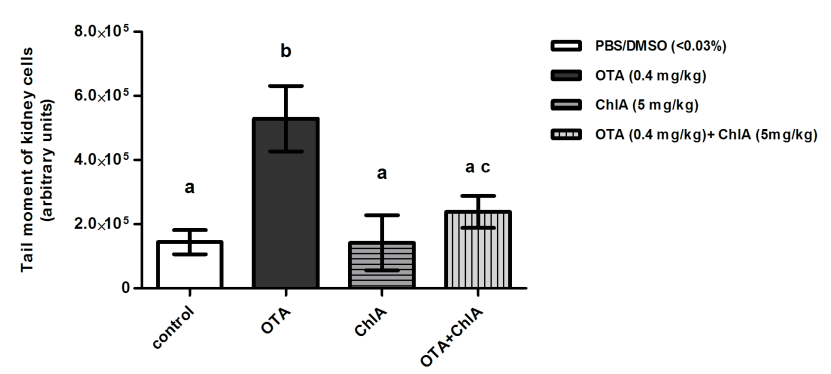

Figure 2. Protective effects of chlorogenic acid (ChlA) on ochratoxin A (OTA)-induced DNA damage (tail moment) measured by comet assay. A) blood cells or B) kidney cells from Wistar rats $(n=4)$ aî†er 28 days of treatment. Each value representhe means \pm SD. Statistical test: Kruskal-Wallis and Dunns Test. c: $\mathrm{p}<0.05$ compared with OTA group.

Figures $2 \mathrm{~A}$ and $\mathrm{B}$ show the results of the comet assay. In OTA-treated group an increase in tail moment of the blood and kidney cells compared to control group $(\mathrm{p}<0.001)$ was observed. However, treatment of the animals with OTA+ChlA produced a decrease in DNA damage by $37 \%$ in blood cells and by $55 \%$ in kidney cells $(\mathrm{p}<0.05)$ with respect to OГA. The micronucleus assay results are shown in Table 1. An increase in the frequency of micronucleus $(\mathrm{MN})$ in polychromatic erythrocytes (PCE) in OTA-treated group compared to control group $(\mathrm{p}<0.001)$ was observed. The frequency of $\mathrm{MN}$ in PCE was reduced by $80 \%$ with OFA+ChlA acid treatment compared to OTA-treated group $(\mathrm{p}<0.001)$. No differences were observed in the $\mathrm{PCE} /$ normochromatic erythrocytes (NCE) ratio in any group. Cellular DNA of animals treated with only Ch1A was not altered. 
Table 1. Protective effects of chlorogenic acid (ChlA) on ochratoxin A (OTA) induced genotoxic effects on bone marrow erythrocytes from Wistar rats after 28 days of treatment.

\begin{tabular}{lcll}
\hline Treatments & Wistar & TI & GI \\
& rats (n) & (PCE/NCE \pm SD) & MNPCE (\%) \\
\hline Negative control (DMSO/PBS) & 4 & $1.38 \pm 0.50$ & $8.50 \pm 2.12 \mathrm{a}$ \\
OTA $(0.4 \mathrm{mg} / \mathrm{kg} \mathrm{bw})$ & 4 & $1.43 \pm 0.16$ & $63.00 \pm 12.73^{\mathrm{b}}$ \\
ChlA $(5 \mathrm{mg} / \mathrm{kg} \mathrm{bw})$ & 4 & $1.33 \pm 0.24$ & $12.50 \pm 2.12^{\mathrm{a}}$ \\
OTA $(0.4 \mathrm{mg} / \mathrm{kg})+$ ChlA $(5 \mathrm{mg} / \mathrm{kg})$ & 4 & $1.41 \pm 0.29$ & $12.50 \pm 0.71^{\mathrm{a}}$ \\
\hline
\end{tabular}

Four rats were used per experimental group; TI: Toxicity Index; GI: Genotoxicity Index; PCE: polychromatic erythrocytes; NCE: normochromatic erythrocytes; MNPCE: micronucleated polychromatic erythrocytes. Statistical test: ANOVA and Tukey`s Test. Different superscript letter indicates statistical significance.

\section{Discussion}

This work evaluated the protective effect of ChlA administered orally on DNA damage in Wistar rats exposed to OTA. Body weight is an important indicator of toxicity; however, this parameter was not altered in any treatment group. In a previous study we observed similar results (Cariddi et al., 2016). In the present study we reported the DNA damage induced by OTA on blood cells and bone marrow cells, as reported previously by our laboratory (Cariddi et al., 2015) as well as by other authors (Corcuera et al., 2015). We also found DNA damage in kidney cells of animals treated with OTA, as demonstrated by other researchers (Abdel-Wahhab et al. 2017). Some studies have related OTA damage in kidney with carcinogenicity (Tajik et al., 2017). The protective effect of ChlA on DNA damage induced by OTA was already demonstrated in a previous study (Cariddi et al., 2015). However, in that study both polyphenol and mycotoxin were administered intraperitoneally, and the protective effect was evaluated 24 hours postinjection. In the present study, oral administration of ChlA during 28 days in rats exposed to OTA also protected from the genotoxicity induced by this mycotoxin. Chlorogenic acid is a powerful natural antioxidant (Xu et al., 2012). In this study, oral treatment of rats with only ChlA did not alter DNA of cells. Other studies have also demonstrated the lack of toxicity of this compound (Wang et al., 2020). In a previous study in rats exposed to OTA we demonstrated that the oral administration of ChlA reversed the pathological damage induced by this mycotoxin in kidneys, as well as the biochemical parameters altered in urine and serum. However, we did not observe an increase in the oxidative stress parameters measured in kidneys of OTA-treated animals, indicating a protective effect of ChlA but not by an antioxidant mechanism (Cariddi et al., 2016). Although some studies report oxidative DNA damage induced by OTA in kidneys 
(Abdel-Wahhab et al., 2017), this is controversial because several authors demonstrated a lack of oxidative damage associated to the toxic effects caused by this mycotoxin (Köszegi \& Poór, 2016). The results suggest that ChlA could be protecting cellular DNA from the damage induced by OTA by a different mechanism.

In conclusion, oral treatment with ChlA decreased DNA damage induced by OTA exposure in blood, bone marrow and kidney cells showing a good protective activity that may be important for the prevention of ochratoxicosis in susceptible animals.

\section{Acknowledgements}

This work was supported by grants from Consejo Nacional de Investigaciones Científicas y Técnicas, Argentina (CONICET), Programa PID from Ministerio de Ciencia y Tecnología, Gobierno de la Provincia de Córdoba Resolution \#000018/14 years 2014/17, and CNPq and FAPERJ from Universidade Federal do Rio de Janeiro. Mic. Noelia Campra is a doctoral fellow of CONICET. Dr. Laura Noelia Cariddi, Dr. Franco Escobar and Dr. Carola Sabini are researchers of CONICET. Special thanks to Dr. Ana Dalcero, who passed away in August 2016.

\section{Competing interests}

The authors declare that there are no conflicts of interest.

\section{References}

Abdel-Wahhab MA, Aljawish A, El-Nekeety AA, Abdel-Aiezm SH, Hassan NS. 2017. Chitosan nanoparticles plus quercetin suppress the oxidative stress, modulate DNA fragmentation and gene expression in the kidney of rats fed ochratoxin A-contaminated diet. Food and Chemical Toxicology. 99:209-21. https://doi.org/10.1016/j.fct.2016.12.002

Cariddi LN, Sabini MC, Escobar FM, Montironi I, Mañas F, Iglesias D, Comini LR, Sabini LI, Dalcero AM. 2015. Polyphenols as possible bioprotectors against cytotoxicity and DNA damage induced by ochratoxin A. Environmental Toxicology and Pharmacology. 39: 1008-18. https://doi.org/10.1016/j.etap.2015.03.013

Cariddi LN, Escobar FM, Sabini MC, Campra NA, Bagnis G, DecoteRicardo D, Freire-de-Lima CG, Maas F, Sabini LI, Dalcero AM. 2016. Phenolic acid protects of renal damage induced by ochratoxin A in a 28days-oral treatment in rats. Environmental Toxicology and Pharmacology. 43:105-11. https://doi.org/10.1016/j.etap.2016.03.004

Carranza-Torres IE, Viveros-Valdéz E, Guzmán-Delgado NE, García-Davis S, Morán-Martínez J, Betancourt-Martínez ND, Balderas-Rentería I, Carranza-Rosales P. 2019. Protective effects of phenolic acids on mercury-induced DNA damage in precision-cut kidney slices. The Iranian 
Journal of Basic Medical Sciences. 22(4):367-75.

https://doi.org/10.220 38/ijbms.2019.30056.7242

Corcuera LA, Vettorazzi A, Arbillaga L, Pérez N, Gil AG, Azqueta A, González-

Peñas E, García-Jalón JA, López de Cerain A. 2015. Genotoxicity of aflatoxin B1 and ochratoxin A after simultaneous application of the in vivo micronucleus and comet assay. Food and Chemical Toxicology. 76:116-24. https://doi.org/10.1016/j.fct.2014.12.003

Jackson P, Pedersen LM, Kyjovska ZO, Jacobsen NR, Saber AT, Hougaard KS, Vogel U, Wallin H. 2013. Validation of freezing tissues and cells for analysis of DNA strand break levels by comet assay. Mutagenesis. 28(6):699-707. https://doi.org/10.1093/mutage/get049

Kőszegi T, Poór M. 2016. Ochratoxin A: Molecular interactions, mechanisms of toxicity and prevention at the molecular level. Toxins (Basel). 8(4): 111. https://doi.org/10.3390/toxins8040111

Muzaffer D, Pérez JF. 2006. Contaminación por micotoxinas en los piensos: efectos, tratamiento y prevención. XXII Curso de Especialización FEDNA. 1-17.

Mazur-Kuśnirek M, Antoszkiewicz Z, Lipiński K, Fijałkowska M, Purwin C, Kotlarczyk S. 2019. The effect of polyphenols and vitamin $E$ on the antioxidant status and meat quality of broiler chickens fed diets naturally contaminated with ochratoxin A. Archives of Animal Nutrition. 73(6): 431-44. https://doi.org/10.1080/1745039X.2019.1639445

Quiñones M, Miguel M, Aleixandre A. 2012. Los polifenoles, compuestos de origen natural con efectos saludables sobre el sistema cardiovascular. Nutrición Hospitalaria. 27(1):76-89. https://doi:10.1590/S0212-16112012000100009

Ravelo Abreu A, Rubio Armendáriz C, Gutiérrez Fernández AJ, Hardisson de la Torre A. 2011. La ocratoxina A en alimentos de consumo humano: revisión. Nutrición Hospitalaria. 26(6):1215-26. https://doi.org/10.159 0/S0212-16112011000600004

Tajik N, Tajik M, Mack I, Enck P. 2017. The potential effects of chlorogenic carqu, the humantp: phenolic components in coffee, on health: a comprehensive review of the literature. European Journal of Nutrition, 56:2215-44. https://doi.org/10.1007/s00394-017-1379-1

Vettorazzi A, González-Penas E, López de Cerain A. 2014. Ochratoxin A kinetics: A review of analytical methods and studies in rat model. Food and Chemical Toxicology, 72: 273-88. https://doi.org/10.1016/j.fct.2014.07.020

Wang H, Wei Y, Xie Y, Yan C, Du H, Li Z. 2020. Ochratoxin A and fumonisin $\mathrm{B} 1$ exhibit synergistic cytotoxic effects by inducing apoptosis on rat liver cells. Toxicon, 181:19-27.

https://doi.org/10.1016/j.toxicon.2020.04.094

Xu JG, Hu QP, Liu Y. 2012. Antioxidant and DNA-protective activities of chlorogenic acid isomers. Journal of Agricultural and Food Chemistry, 60: 11625-30. https://doi.org/10.1021/jf303771s 